\title{
Bialahin Concept: Reflections on the Unity of the Buru People in Maluku
}

\author{
Dortje L. Y. Lopulalan* \\ Post Doktoral Departmen of Sociology \\ Universitas Negeri Makassar \\ Makassar, Indonesia \\ nor_lopulalan@yahoo.co.id
}

\author{
Jumadi \\ Departemen Sociological Science \\ Faculty of Social Science \\ Universitas Negeri Makassar \\ Makassar, Indonesia \\ Jumadi@unm.ac.id
}

\author{
Muhammad Syukur \\ Departmen of Sociology \\ Faculty of Social Science \\ Universitas Negeri Makassar \\ Makassar, Indonesia \\ m.syukur@unm.ac.id
}

\begin{abstract}
This qualitative study aimed to understand whether Bialahin (pear sago) can be a reflection and spirit of the unity of the Buru community that can serve as a pattern of leadership theory in Maluku today. Actually the concept of Bialahin, is the concept of strong unity that forms solidarity among the Moluccan people, is believed to have unwittingly become a symbol of the Buru community in Maluku. The concept of Bialahin has actually also been implemented in the context of leadership called "Basafena or Gebakuasan" which seems to have occupied a central position and is surrounded by members of the community. The life unity of the Bialahin concept is described in the sago plant family, its relationship with the development of functional structures in society and organizations will be seen in the pattern of leadership played by a leader. The study to understand these concepts and reflections, there are a number of supporting theories (Tacolt Parsons as structural theories, Nonaka-takeuchi, as tori creations of individual knowledge) have been used to see how Bialahin as a reflection of unity and identical theories of Buru people can be a reflection the spirit of unity of the Buru community in Maluku. To analyze data collected from Regenchap, a traditional battle area, this study uses a structural functional approach. This study was successfully carried out in Kayeli, Buru Regency, Maluku Province. From his findings in broad outline it can be concluded: The concept of bialahin as a reflection of the unity of the Buru community can be used as a pattern of leadership in Maluku, especially during the Maluki community resolution. This concept leadership shows the behavior of sharing knowledge with group members, creating their own source of energy for members to have mutual trust, the same fate, cooperation, to form a bialahin ecosystem that is interrelated with each other in action, maintaining the balance of the Maluku community system itself.
\end{abstract}

Keywords: Bialahin, Life Unity, Maluku Buru Society, and Leadership Theory

\section{INTRODUCTION}

Life unity is an emotional and cultural closeness between members of the community to form a community by including certain identities [1]. Unity of life-related to the community aspects of society. Community is a unity of local life based on the bond of the place of life, an inner bond that makes people always feel attached to their old community. The unity of the Buru community actually originated from the concept of bialahin (sago tree), which consists of 3-5 houses following the biological structure of the sago tree, where trees from the genus Metroxylon and the Arecaceae family or belong to the Palmae family [2][3], are plants that storing starch on the stem.

The socio-cultural philosophy of the Buru indigenous people conceptualizes bialahin as consisting of two words: bialahin means sago and Latin can mean trees and roots, so bialahin refers to sago trees. The Buru kinship system called bialahin which shows a sub-group of a kinship group (clan). The leader of the bialahin is called. Basafena or Gebakuasan who occupies the middle position and is surrounded by its members.

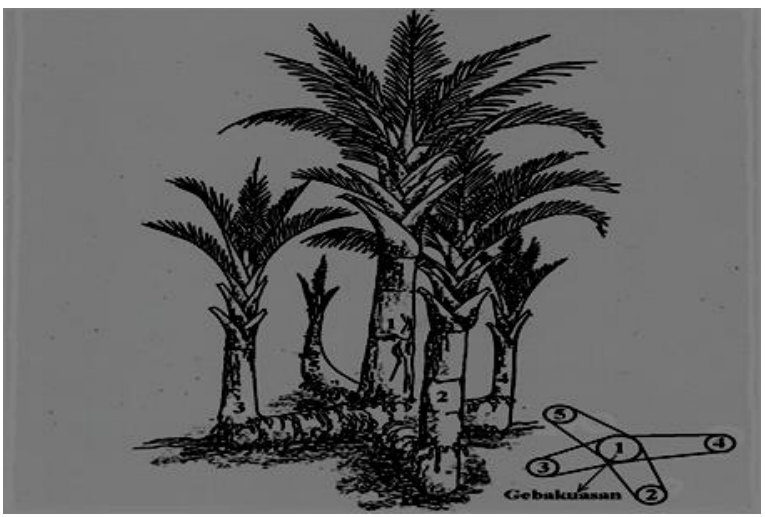

Figure 1. Sago grove (Louhenapessy, 1992).

Based on the position of the tree (1) is the parent of one family. Tree (2) is a substitute candidate for the tree (1), as well as trees (3), (4) and (5). Trees (1) will give other trees a chance to live if they are cut down before the presence of trees (5). As long as the tree (1) survives, the others will not pass over it. From these sago groves, there is an energy flow between one another. Bialahin life unit depicted in sago groves. Functionally the life unity of bialahin will be seen by the pattern of leadership played by a leader. Because the purpose of this study is to analyze bialahin (Sago Tree) as a reflection of the unity of Buru people. The question is raised. Can it be used as a pattern of community leadership in Maluku?

Supporting theory used to study the research focus on how bialahin (sago tree) as a reflection of the unity of the Buru people can be used as a pattern of leadership in Maluku, is a functional structural theory by Tacolt Parsons. The theory of Structural Functionalism is part of the social facts paradigm, which examines both visible and invisible social facts. Changes that occur in one section will cause 
changes in other parts. The basic assumption is that every social structure and social system has a functional part or element to other parts or elements. Conversely, if it is not functional, the structure will not exist or will disappear by itself [4][5]. This theory basically views society as a system consisting of system elements that are interrelated and work according to their respective functions. That way, every existing system contributes to an equilibrium (balance).

This theory also explains that social structure and social institutions are related to the function of social facts. The function in this theory is related to the effects that can be observed in the process of adaptation or adjustment of a system. Structural functionalism runs through individuals as actors by carrying out their respective functions and roles through adaptation to the structural subsystem of functionalism, which results in an action (unit of action). From this action unit, then there is an active system where the community has found the purpose of the action. So that a society is formed with its own uniqueness. Later, more complex changes will occur [6]. The functionalism perspective offers several functional requirements or requirements that must be met for a social system to survive. some of these requirements include:

a. Adaptation (Adaptation), A system of adjustment to the existing environment must be able to survive when the external situation is not supportive. The system is required to be able to overcome the needs that come from outside the system.

b. Goal Attainment: a condition that a system needs to have in order to continue to maintain its existence. Without clear goals, there can be no synergy between sub-systems in the existing system. So a system must have a clear direction to try to achieve its main goal. Under these conditions, the system must be able to determine and have the resources to set and achieve goals that are collective.

c. Integration: A system must regulate the relationships between parts that become its components. The system must also be able to manage the relationships between the three other important functions. Integration is a function that regulates the relationship between one part and the other. That said, integration is a factor that creates synergy between one sub-system with sub-systems

d. Latency: a system must complete, maintain, and improve cultural patterns. Latency can also be understood as maintaining patterns. The existing system must be able to create cultural patterns which are then embedded in every individual in the system.

The functional structural theory approach addresses human behavior in complex organizations (communities) and how the behavior is in equilibrium conditions in communities. The basic problem faced by every social organism is how to remain viable and the patterns of interaction between subsystems that occur in it can maintain the integrity of the system. Society as a social system according to Parsons must have at least four imperative functions that are at the same time characteristic of a system. All four are related to the action system, known as the AGIL scheme [7][8].
AGIL a function is a collection of activities that are directed towards meeting certain needs or system requirements. Nonaka and Takeuchi first reintroduced the importance of the process of creating knowledge for individual employees. Knowledge creation can be seen as a process whereby the knowledge possessed by employees as individuals are internalized into the organizational knowledge base [9]. Knowledge is created through interactions between individuals at various levels in the organization. Organizations cannot create knowledge without the role of individuals, the reality does show that if individual knowledge is not shared with other individuals or groups, individual efforts have limitations on the impact of organizational effectiveness. Organizational capacity in optimizing knowledge depends to a large extent on human aspects that can actually create, share, and use that knowledge [10]. According to Quinn knowledge shared will grow exponentially. If two people exchange knowledge with each other, both will get information and experience that grows linearly. But if both of them then share new knowledge with others and get feedback or modify the exponential usefulness. Sharing knowledge in organizations is part of prosocial behavior. At the individual level, there are three perspectives in looking at humans that determine why someone is willing to share knowledge [11].

First, certain personality characteristics that distinguish one person from others in sharing knowledge. When viewed from the motivation theory, this personality type is called altruistic motivation or internal motivation [12]. Altruistic motivation is based on empathy so that the ultimate goal is the welfare of colleagues or other groups. For people with altruistic personalities, sharing knowledge is a necessity because sharing knowledge itself is an acknowledgment of the knowledge it has. Sharing your own knowledge is an award.

Therefore, material incentives are not needed. In fact, there are personality characteristics that do correlate with knowledge sharing. Secondly, knowledge sharing is due to external motivation or egoistic motivation [13]. Selfish motivation has the ultimate goal to improve the welfare of the doer on the basis of personal gain, namely reducing self distress. Sharing is not caused by internal needs but because of external stimulus or appreciation. Third, knowledge sharing is caused by the conducive climate created by the organization. This perspective is more interactive, meaning that initial motivation is not a problem but the organization creates a climate such that employees are voluntarily motivated to share knowledge.

In the creation of knowledge, the main prerequisite is trust [14]. Knowledge owners prefer to share knowledge in groups that can be trusted. The fact is that sharing knowledge does not mean the simple transfer of information but it is sharing ideas, beliefs, attitudes, values, anxiety, curiosity, assumptions, and prejudices. Therefore, knowledge sharing is not possible if the climate of trust does not exist [15], so it can be concluded that there is a strong relationship between trust and knowledge sharing [16]. Based on social identity theory, knowledge sharing can be explained when a person has identified with a group or organization so that they 
experience depersonalization, as a result, a sense of shared destiny grows. The feeling of in-group is an embryo for the growth and development of group identity to form mutual trust and belonging.

\section{METHOD}

The paradigm used in the functional structural research method is the functional structural paradigm. This paradigm (functional structural) is aimed at trying to find out the origin of a particular institution or cultural element but on its function in the context of a particular community or cultural life [17]. This relates to the problem that the researcher will explain: "How can bialahin (Sago Tree) as a reflection of the unity of Buru people live as a pattern of leadership in Maluku"? The research approach used is a qualitative approach. This approach was chosen with the consideration that through a qualitative approach, researchers can understand (verstehen) the process, meaning, and results of bialahin (Sago Tree) as a reflection of the unity of the Buru people as a pattern of leadership in Maluku".

This research was carried out in the regenchap (traditional fishing area) Kayeli, Buru Regency, Maluku Province. The data obtained in this study are data about community unity and identity. Key informants (key informants) in this study consisted of, Traditional Characters, and Community Leaders. Data collection techniques used were observation, interviews, and documentation studies [18][19].

\section{RESULT AND DISCUSSION}

Buru Regency is located between $2^{\circ} 25$ 'South Latitude and $3^{\circ} 83^{\prime}$ South Latitude and between $126^{\circ} 08$ 'East Longitude and $127^{\circ} 20^{\prime}$ East Longitude. In the north it borders the Seram Sea, in the south it borders South Buru, in the west it borders South Buru Regency and the Seram Sea, and in the east it borders the Manipa Strait. The capital of Buru Regency, Namlea, is located inside Kayeli Bay. (source: Buru District Office). Likewise, the Buru people live in religious and ethnic diversity but they have a sense of awareness of the high collective ties. Buru is one of the tribes in Maluku and Buru is the second-largest island after Seram Island.

The Buru Regency region includes 8 (eight) regenschap / customary areas, namely Masarete, Leisela, Tagalisa, Liliali, Kayeli, Kayes, Waesama, Fogi, and Ambalau. The system and form of village governance on Buru Island has its own characteristics, compared to regions in Central Maluku. Its peculiarity is evident from its orientation to local customs, which were previously mentioned as petuanan or customary territories (regentschap). Each petuanan was led by a starch king.

Traditionally, a regentschap oversees several villages or villages, which are included in the territory of his administration, while in terms of government administration, regentschap is directly under the sub-district government. Sago tree (Metroxylon $\mathrm{sp}$ ) in growth in nature also represents a kinship relationship. Likewise in the unity of life the Buru people represent a kinship in noro called bialahin. In one bialahin they usually settle in their land with only three to five houses following the sago groves. The unity of the Buru people in bialahin is very dependent on the decisions taken by Gebakuasan. From the picture of the sago family, the life of a bialahin is strongly maintained and all secrecy of the gebakuasan is faithfully protected by all other members of the bialahin. And it is not easy to break through the unity of the family, especially outsiders will be very difficult to influence the ongoing energy between them.

Based on position, tree (1) is the parent of one family. Tree (2) is a substitute candidate for tree (1), as well as trees (3), (4) and (5). Tree (1) will give another tree a chance to live if it is cut down before the presence of the tree (5). As long as the tree (1) survives, the others will not pass over it. From these sago groves there is an energy flow between one another. Bialahin survival, where the system must be able to adapt to the existing environment must be able to survive when the situation is not supportive.

Bialahin sustainability system is required to be able to overcome the needs that come from outside the system. He is able to adapt to his surroundings. Trees (1) are the parent of a continuous family of trees in synergy with the saplings of trees (2), (3), (4), and (5) as potential substitutes of the trees by synergizing with each other, this is a goal held by a system to be able to continue to maintain its existence, by being able to gather food energy through the propagation of the dense root fibers which fuse and have very flexible breath roots in each change of season, making the food energy source for puppies still well supplied. Bialahin habitat in inundation and root propagation makes the growth of young plants (shoots/seedlings) very rapid, but growth at the tree plant level is very slow. This is a sign that Tree (1) illustrates the dedication of the work carried out by the leader. If the power is judged to be no longer able to lead the life of the community, a replacement will be sought which will continue its role to lead the bialahin group. The characteristics of plants in the family Arecaceae will die starting from the shoots gradually toward the roots. The fragility of the tree's identity (1) stems from shoot damage as a result of stopping energy production, then propagates in the loss of the body and finally destroyed, witnessed by colleagues in one group. When the tree (1) dies it will give new energy to the other tree saplings. If a tree (1) issues betel, its appearance is like a raised human hand as if offering itself to the open sky and surrendering helplessly. and want to say it like this: "take my body and help me because I am already helpless where my life consumes only the energy of the four of you. Thank you for my brother's trees (2), (3), (4) and (5), because you are faithful to maintain my identity to stand tall, only you can understand me but it is actually the wisest step if you act quickly to cut me down before your sibling's tree (5) it appears, knows that the tree (5) also has the right to live in this family, and I want to honestly say that I have become an energy parasite in this family. I cannot continue to survive in this state of imbalance. The time will come when I have to follow the laws of the earth where I have to die because those who govern and rule this life are from the laws of heaven. For this reason, I reached out my hand to surrender myself to the law of heaven (Pattinama, 2017: 5) 
Building the perspective of researchers in this part of the discussion provides an explanation of "How can bialahin (Sago Tree) as a reflection of the unity of life of the Buru people can be used as a pattern of leadership in Maluku"?. Position of bialahin in the tree (1) as a leader in an organization. Based on position, tree (1) is the parent of one family. Tree (2) is a substitute candidate for the tree (1), as well as trees (3), (4) and (5). Tree (1) will give another tree a chance to live if it is cut down before the presence of the tree (5). As long as the tree (1) survives, the others will not pass over it. From these sago groves, there is an energy flow between one another.

Leadership basically cannot walk alone. Leadership arises because of cooperation with others. Without others, there are no leaders, leadership is not the effort of one person alone, but involves teamwork. Trees (1) are the parent of a continuous family of trees in synergy with the saplings of trees (2), (3), (4), and (5) as potential substitutes of the trees by synergizing with each other, this is a goal held by a system to be able to continue to maintain its existence, by being able to gather food energy through the propagation of the dense root fibers which fuse and have very flexible breath roots in each change of season, making the food energy source for puppies still well supplied. The structural-functional approach approaches to discussing human behavior in the complex of the organization (society) and how the behavior of the leader (individual) is in (can maintain) the equilibrium condition in the organization/society.

The basic problem faced by every social organism is how to remain viable and the patterns of interaction between subsystems that occur in it can maintain the integrity of the system. Society as a social system according to Parsons must have at least four imperative functions that are at the same time characteristic of a system. All four are related to the action system, known as the AGIL scheme. AGIL a function is a collection of activities that are directed towards meeting certain needs or system requirements. By using this definition, Parsons believes that there are four important functions needed for all systems. The integration of a system must regulate the relationships between the parts that become its components. The system must also be able to manage the relationships between the three other important functions.

Integration is a function that regulates the relationship between one part and the other. That said, integration is a factor that creates synergy between one subsystem with other sub-systems. This function is also tasked with regulating the relationship between the function of adaptation, goals, and latency, where the existing system must be able to create motivation and cultural patterns that are then embedded in every individual in the system.

Bialahin habitat in inundation and root propagation makes the growth of young plants (shoots/seedlings) very rapid, but growth at the tree plant level is very slow. This is a sign that Tree (1) illustrates the dedication of the work carried out by the leader. If the power is judged to be no longer able to lead the life of the community, a replacement will be sought which will continue its role to lead the bialahin group. Who has contributed to building a climate of trust in groups or organizations? Trust is a process created in an organization. Commitment to sharing knowledge is influenced by leadership especially in the context of high power distance.

The bialahin leadership style used will foster trust for followers, which is a capital for the growth and development of knowledge sharing. Based on social identity theory, knowledge sharing can be explained when a person has identified with a group or organization so that they experience depersonalization, as a result, a sense of shared destiny grows. The feeling of in-group is an embryo for the growth and development of group identity to form mutual trust and belonging. This situation is a conducive climate for the growth of knowledge sharing.

Therefore, someone will be more prepared and willing to share knowledge with those who are trusted and who have been known (ingroup) because it is based on trust that grows in him, as revealed in the bialahin philosophy when a tree (1) dies will give new energy to saplings another. If a tree (1) takes out a betel fruit, its appearance is like a raised human hand as if offering itself to the open sky and surrender helplessly, and want to say like this: "take my body and help me because I am already helpless where my life only consumes four of your energy. Thank you my brother's trees (2), (3), (4) and (5), because you are faithful to maintain my identity to stand tall, only you can understand me but it is actually the wisest step if you act quickly to cut me down before your sibling's tree (5) it appears, knows that the tree (5) also has the right to live in this family, and I want to honestly say that I have become an energy parasite in this family.

Abhisek Srivastava and Sari show that leadership is directly related to knowledge sharing. In reality, the problem of sharing knowledge is to distribute authority. Knowledge is power [20]. Therefore it is said French and Raven sharing knowledge means an eruption from the power of the leader [21]. Therefore, the leadership factor has a strategic dimension in cultivating knowledge sharing. Based on the explanation, it can be said that knowledge sharing is a process of social interaction that occurs in organizations. When knowledge management is the strategy chosen by the organization, knowledge sharing is an important factor. Feeling the same fate between members formed through a long process will certainly form trust (trust), the life of the Buru people in bialahin is very dependent. From the picture of the sago tree family, the life of a bialahin is strongly maintained and all secrecy of the Gebakuasan is faithfully protected by all other members of the bialahin. And it is not easy to break through the unity of the family, especially outsiders will be very difficult to influence the ongoing energy between them.

In the perspective building "bialahin (Sago Tree) as a reflection of the unity of the Buru people can be used as a pattern of leadership in Maluku" with the model described as follows: 


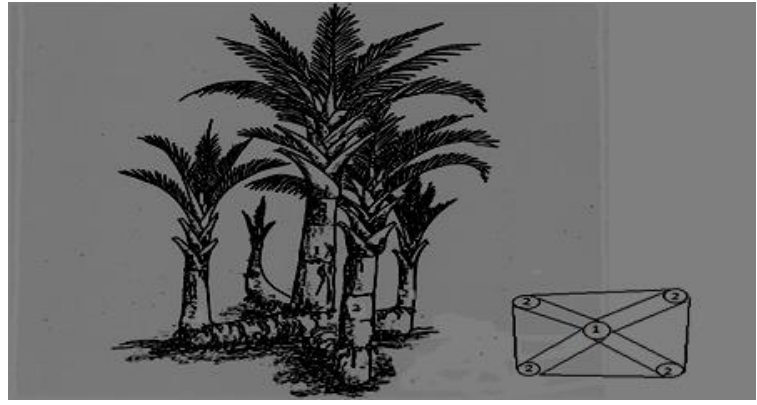

Figure 2. Sago groves (bialahin) as a reflection of the unity of Buru people can be used as a pattern of leadership in Maluku. Caption: 1. Is a leader (gebakangan) who shares knowledge. 2. Is a member who has mutual trust, has the same fate and can work together. Trees (1) and trees (2) exist in a bialahin ecosystem that is interconnected to form an action system to be able to maintain the balance of the system. Thus bialahin (sago tree) provides a pattern of leadership that shares knowledge, does not want to win alone, and does not want to be in power forever over its position. That is why natural ecosystems are the most important part of Buru's way of life and local wisdom as a whole of the cosmos.

\section{CONCLUSION}

The sago family (bialahin) as a reflection of the unity of the Buru people can be used as a pattern of leadership in Maluku. Leaders (gebak domes) show behavior that shares knowledge with members making their own source of energy for members to have one another, believe in the same fate and be able to work together to form a bialahin ecosystem that is interconnected in the action system to be able to maintain the equilibrium conditions of the system itself.

\section{ACKNOWLEDGMENT}

Special appreciation also given to all informants who are faithfully sharing valuable information to us so that all data needed in the research can be collected.

\section{REFERENCES}

[1] S. Koschut, "Appropriately upset? A methodological framework for tracing the emotion norms of the transatlantic security community," Polit. Gov., vol. 6, 2018.

[2] M. J. Pattinama, A. Boreel, J. K. J. Laisina, and H. E. P. Leimena, "Resource Potential Of Snake Fruit (Salacca zalacca var Amboinensis) And Canary (Canarium Amboinense) In The Life Of Seram Island Society, Moluccas."

[3] M. J. Pattinama, I. DEA, Y. Tasijawa, R. Tasijawa, and J. E. Uneputty, "CERITA TENTANG TEMPAT KERAMAT DI DATARAN RANA, PULAU BURU, MALUKU."

[4] G. Ritzer and J. Stepnisky, Contemporary sociological theory and its classical roots: The basics. SAGE Publications, 2017.

[5] G. Ritzer and J. Godman, "Douglas. 2010," Teor. Sosiol. Mod.
[6] B. Raho, Teori sosiologi modern. Prestasi Pustaka, 2007.

[7] J. Habermas, "Talcott Parsons: Problems of theory construction," Sociol. Inq., vol. 51, no. 3-4, pp. 173196, 1981.

[8] D. Sciulli and D. Gerstein, "Social Theory and Talcott Parsons in the 1980," Annu. Rev. Sociol., vol. 11, no. 1, pp. 369-387, 1985.

[9] I. Nonaka and H. Takeuchi, The knowledge-creating company: How Japanese companies create the dynamics of innovation. Oxford university press, 1995.

[10] M. Ipe, "Knowledge sharing in organizations: A conceptual framework," Hum. Resour. Dev. Rev., vol. 2, no. 4, pp. 337-359, 2003.

[11] S.-H. Liao, W.-C. Fei, and C.-C. Chen, "Knowledge sharing, absorptive capacity, and innovation capability: an empirical study of Taiwan's knowledge-intensive industries," J. Inf. Sci., vol. 33, no. 3, pp. 340-359, 2007.

[12] S. Guimond, Social comparison and social psychology: Understanding cognition, intergroup relations, and culture. Cambridge University Press, 2006.

[13] H. Hall and D. Graham, "Creation and recreation: motivating collaboration to generate knowledge capital in online communities," Int. J. Inf. Manage., vol. 24, no. 3, pp. 235-246, 2004.

[14] S. S. S. Fu and M. K. O. Lee, "IT Based Knowledge Sharing and Organizational Trust: The Development and Initial Test of a Comprehensive Model," 2005.

[15] C. G. L. Nerstad, R. Searle, M. Černe, A. Dysvik, M. Škerlavaj, and R. Scherer, "Perceived mastery climate, felt trust, and knowledge sharing," $J$. Organ. Behav., vol. 39, no. 4, pp. 429-447, 2018.

[16] A. J. Lambert, B. K. Payne, L. L. Jacoby, L. M. Shaffer, A. L. Chasteen, and S. R. Khan, "Stereotypes as dominant responses: On the" social facilitation" of prejudice in anticipated public contexts.," J. Pers. Soc. Psychol., vol. 84, no. 2, p. 277, 2003.

[17] H. S. Ahimsa-Putra, "Strukturalisme Levi-Strauss: Mitos dan Karya Sastra," Yogyakarta: Galang Printika, 2001.

[18] A. Agustang, "Dasar-Dasar Filsafat Penelitian Untuk Pengembangan Ilmu." CV Multi Global, Jalan Maccini Sawah, 2015.

[19] A. Agustang, "Pendekatan Penelitian Kualitatif dan Kuantitatif Suatu Tinjauan Kritis," Makassar Andira Publ., 2011.

[20] K. Husted and S. Michailova, "Diagnosing and fighting knowledge-sharing hostility," Organ. Dyn., vol. 31, no. 1, pp. 60-73, 2002.

[21] R. E. Anderson, "Implications of the information and knowledge society for education," in International handbook of information technology in primary and secondary education, Springer, 2008, pp. 5-22. 